\title{
Em Cabo Verde, os Marginais, de Evel Rocha: justiça social e gênero
}

\author{
In Cape Verde, Marginais, by Evel Rocha: social \\ justice and gender
}

\author{
MÁrio CÉSAR Lugarinho*
}

...e me suicido na tentativa de me transformar em poema e poder, enfim, circular livremente

(Al Berto)

lgo novo despontou na Literatura Cabo-verdiana e, por conseguinte, no conjunto das Literaturas Africanas de Língua Portuguesa. Marginais, de Evel Rocha, publicado em 2010, narra a vida de um jovem criado às margens de uma sociedade em transformação. Iniciada em 1977, ano de nascimento de Sérgio, a narrativa chega à sua morte, em 1999.

O pano de fundo é o processo de constituição do Estado-nação caboverdiano e a crescente urbanização de sua população. O espaço narrativo é a Ilha do Sal, centro turístico, polo de atração de grandes investimentos internacionais. Narrado em primeira pessoa, o relato consiste nas memórias de Sérgio Pitboy, supostamente entregues ao autor após um encontro casual. A narrativa principia pelo encontro, quando somos apresentados ao protagonista, já em adiantada situação de risco social e degradação física. Ao receber os manuscritos, o autor expressa o seu juízo: "Este é um livro que muitos jovens deste país gostariam de ter escrito" (ROCHA, 2010, p. 13).

* Universidade de São Paulo, São Paulo, São Paulo, Brasil. E-mail: lugarinho@usp.br. 
Em Marginais, o espaço é privilegiado, porque, como as personagens, constitui-se também à margem da cidade. É o espaço da periferia urbana, não um espaço geográfico específico, mas espaço "subterrâneo", onde se assentam as cidades idealizadas (v. FREITAG, 2002). Na Ilha do Sal ficam evidentes os influxos modernizadores da globalização. Sérgio Pitboy transita da cidade subterrânea e periférica ao centro de povoação burguesa e de atração turística da ilha, instalando-se na condição de marginal. Mas, apesar da situação social de risco, Sérgio mantém o sonho de habitar aqueles centros e constituir-se no espaço social aburguesado, seja formando-se em Direito, seja como jogador de futebol em Portugal, seja como cantor de rap. Os sonhos de sucesso são os fios que o atam aos anseios maternos, ao reencontro almejado com a mãe, que experimentará a emigração anos após o seu nascimento. No entanto, sua marginalização continuada, um processo inexoravelmente descendente, faz Sérgio se confrontar com situações limites que pulverizam os seus anseios de ascensão.

Marginais é um romance de formação, acompanhando o desenvolvimento físico, sexual, psicológico e social do protagonista, mas escapa ao cânone. A obra está mais próxima de narrativas mais contemporâneas, como a do cubano Pedro Gutierrez (El Rey de La Habana, 1999), ou dos brasileiros Jorge Amado (Capitães de areia, 1937), Ferréz (Capão pecado, 2000) e, mesmo, do romance reportagem de Celso Athayde, MVBill e Luis Eduardo Soares (Cabeça de porco, 2005). Mas, ao contrário da literatura do século XIX, não há mais orientação ofertada pelo modelo social burguês; ao leitor é apresentado o universo das populações das periferias das cidades, onde a inexistência de um poder público que organize o espaço já predestina cada personagem antes de seu nascimento.

Nesse sentido, Marginais é uma narrativa que facilmente se insere na tradição literária cabo-verdiana dos tempos coloniais, pelos mesmos elementos que a singularizam nesse conjunto. Sua "novidade" consiste no espaço, que não oferece mais sentido, como acontecia na produção mais tradicional. Se a terra, tanto na geração claridosa, quanto naquelas que lhe seguiram, oferecia sentido a um anseio de identidade nacional autônoma, em Marginais essa mesma terra perde o seu estatuto privilegiado - espaço geográfico onde a nação se concretiza. A terra é esvaziada de sentido porque a nação é representada por um Estado indolente, incapaz de ser a entidade capaz de promover a justiça e a estabilidade social, com políticas efetivas de inclusão e socialização. 
Em Marginais, o estado é cartorial, "pertence" às classes mais abastadas, e o exercício do poder público apenas garante a estratificação e a perpetuação de condições de injustiça, já que suas faces, a escola, a polícia ou o poder judiciário, garantem apenas a manutenção do status quo. Aos "marginais" não são oferecidas oportunidades de escaparem ao "sistema", restando-lhes o crime, o tráfico e a prostituição. Alternativas são opções idealizadas e usuais como o esporte ou a música. Por isso, no espaço narrativo da Ilha do Sal, os "marginais" transitam invisíveis. Marginais atualiza esses espaços temporalmente, mas, também, porque a partir deles emergem discursos que se confrontam com a ordem social e nos quais se verifica uma violência cotidiana e endêmica.

Evadir-se das ilhas não é opção, é apenas esperança; o isolamento é condição atávica; e a morabeza é subvertida pelo cotidiano. A solidariedade, que garantiria a estabilidade social, política e cultural, só é experimentada entre os indivíduos que compartilham algumas experiências porque localizados num mesmo grupo específico, identificados por idade e proximidade social, geográfica e/ou afetiva - a gangue urbana.

Mas se o marcador de classe social, nessa narrativa, é instrumento para a verificação de exclusão, resta aos indivíduos, em situação social de risco, o marcador de gênero, o recurso possível para a individuação e o destaque social almejado. O reconhecimento passa pela manifestação de caracteres físicos, pela iniciação sexual e suas práticas e, também, pelo desconhecimento de regras e desafios aos parâmetros sociais burgueses que organizam as cidades modernas.

Nas memórias de Sérgio, Fusco é personagem que ocupa lugar privilegiado por sua ousadia, pelo poder de sedução e por suas performances desafiadoras frente aos dispositivos de repressão com que se depara. Sérgio nunca rejeitara Fusco, pelo contrário, além da amizade, ambos passaram a compartilhar suas intimidades. Em Marginais, a prática sexual é naturalizada, inclusive a homossexual. Após Fusco, a relação que, por volta dos seus vinte anos, Sérgio mantém com Valdomiro/Mirinha é reveladora. Se, num primeiro momento a prática de relações homoeróticas foi motivo de curiosidade e de iniciação sexual, Sérgio, mais adulto, é atravessado pelo afeto por Mirinha, mesmo quando submetido à compaixão. Além disso, em Marginais, a sexualidade é naturalizada e é experimentada através de estupros e violações, principalmente praticada pelos aparelhos estatais de segurança. 
Sérgio concentra-se na valorização das relações oferecidas pelos afetos e, também, por um senso de justiça que busca o reparo da (des)ordem social. Após a morte de Mirinha, Sérgio se confronta com a morte de Mirna, com quem também desenvolvera uma intensa relação de afeto que, apesar de ter sido de duração mais longa e mais perene, fora idêntica àquela que mantivera com Mirinha - ou seja, também comovido por compaixão.

A narrativa de Evel Rocha, exposta de maneira resumida, revela-se como manancial para questionamentos acerca dos vários sentidos a que a crítica literária se acostumou, em sua tradição, ao ler o conjunto das Literaturas Africanas de Língua Portuguesa. Rocha subverte esses sentidos ao dar relevo, no que toca à cultura e à sociedade cabo-verdianas, a personagens que estão longe dos estereótipos - sem pudores, os vícios, os crimes, as transgressões, a miséria, a fome, a desigualdade, a injustiça comparecem na narrativa. $\mathrm{O}$ narrador não se anima pela utopia e, por isso, não se alinha a nenhuma outra produção anterior. Nem a terra, nem a nação, nem o povo são capazes de oferecer algum sentido que escape ao fatalismo da corrupção e degradação social. Resta aos marginais, de Evel Rocha, no entanto, um sentido de justiça social que emanaria dos juízos de Sérgio Pitboy, resgatados do senso comum, e que se assenta sobre o seu senso de masculinidade.

A leitura da narrativa de Evel Rocha impõe-nos uma tentativa vã de resposta à pergunta de Gayatri Spivak em seu já clássico "Pode o subalterno falar?" (SPIVAK, 2010). A perspectiva nada otimista da socióloga indiana encontra respaldo nessa narrativa, em que as personagens estão presas à inexorabilidade das categorias de classe e gênero - é preciso lembrar que o discurso de Sérgio é mediado pela narrativa do "autor" que acolhe seus manuscritos e os coloca em circulação. A subversão, da ordem social ou da ordem de gênero, é ação já prevista pelos dispositivos de controle que se adensaram no mundo globalizado e pós-moderno. Não haveria, assim, saídas àqueles que transitam pela narrativa de Rocha, a não ser, possivelmente, o acesso ao discurso. A realização de Marginais é a resposta à urgência com que o autor e o narrador sublinharam a própria narrativa desde as suas primeiras páginas. Ao se tornar narrativa e literatura, Sérgio pode circular livremente. 


\section{Referências bibliográficas}

FREITAG, Bárbara. Cidade dos homens. Rio de Janeiro: Tempo Brasileiro, 2002.

ROCHA, Evel. Marginais. Praia: ASA/Gráfica da Praia, 2010.

SPIVAK, Gayatry Chakravorty. Pode o subalterno falar? Belo Horizonte: Editora da UFMG, 2010.

Recebido em 15 de junho e aprovado em 16 de outubro de 2012. 